\author{
Andrzej ZBROWSKI ${ }^{1}$ \\ Krzysztof JANKOWSKI ${ }^{2}$
}

\title{
TEST ROZTŁACZANIA W KONTROLI JAKOŚCI TULEI POLIMEROWYCH
}

\begin{abstract}
W pracy zaprezentowano zastosowanie w procesie kontroli jakości wyrobów gotowych metody roztłaczania tulei polimerowych wykonywanych z nylonu. Przedstawiono problemy związane $\mathrm{z}$ technologią montażu tulei, na podstawie których są określane wymagania jakościowe w zakresie parametrów wymiarowych i wytrzymałościowych. Podkreślono fakt, że podstawowym problemem technologicznym występującym podczas wtłaczania polimerowej tulei w metalową obudowę jest pękanie polimeru spowodowane oddziaływaniem siłowych obciążeń technologicznych. Sformułowano podstawowe wymagania dotyczące reprezentatywnego testu kontrolnego odtwarzającego wymuszenia zbliżone do warunków rzeczywistych. Badania tulei przeprowadzono metodą roztłaczania, polegającą na statycznym wciskaniu w badany element zgłębnika w postaci stalowego stożka o kącie $30^{\circ}$. Proces badań prowadzono, aż do zniszczenia każdej badanej tulei. Zastosowanie prezentowanej metody przedstawiono na przykładzie dwóch typów tulei polimerowych formowanych w technologii wtrysku ciśnieniowego z tworzywa Zytel 79G13. Badane tuleje stanowią komponent składowy łącznika elastycznego stosowanego w budowie układów zawieszenia samochodów osobowych. Pierwszym rodzajem były tuleje kołnierzowe $\mathrm{z}$ kształtowym pogrubieniem kołnierza występującym na fragmencie obwodu, drugim zaś tuleje kołnierzowe $\mathrm{z}$ kołnierzem osłabionym poprzez wybranie pełniące rolę gniazda ustawczego. Zarejestrowane charakterystyki obciążenia badanych próbek cechują się stabilnością wyników określających siłę niszcząca, przemieszczenie niszczące i sztywność statyczną badanego układu. Charakter wywołanego uszkodzenia jest bardzo podobny do uszkodzeń powstających w rzeczywistych warunkach wymuszeń siłowych. Zarejestrowane charakterystyki obciążania wykazują jednak znaczną różnicę w przebiegu procesu dla obu grup badawczych, spowodowaną odmienną w obu badanych przypadkach sztywnością statyczną układu badawczego. Na podstawie wyników przeprowadzonych badań sformułowano stwierdzenie, że metodę można stosować w bieżącej kontroli jakości gotowych wyrobów występujących w postaci tulei, otrzymywanych z nylonu w technologii wtrysku ciśnieniowego.
\end{abstract}

Słowa kluczowe: nylon, technologia montażu, pękanie, stożek roztłaczający

\footnotetext{
${ }^{1}$ Autor do korespondencji/corresponding author: Andrzej Zbrowski, Instytut Technologii Eksploatacji - Państwowy Instytut Badawczy, ul. Pułaskiego 6/10, 26-600 Radom, tel.: (48) 3644118, fax: (48) 3644760, e-mail: andrzej.zbrowski @itee.radom.pl

${ }^{2}$ Krzysztof Jankowski, Instytut Technologii Eksploatacji - Państwowy Instytut Badawczy, ul. Pułaskiego 6/10, 26-600 Radom
} 


\section{Wprowadzenie}

Tuleje polimerowe wykonane z nylonu, ze względu na bardzo dobre właściwości ślizgowe i tłumiące, są często wykorzystywane jako panewki łożyskowe lub komponenty łączników elastycznych stosowanych w układach kierowniczych i układach zawieszenia samochodów $[1,2]$. Montaż tulei jest realizowany poprzez wciskanie łącznika w piastę stanowiącą element korpusu. Ze względu na wymaganą dużą precyzję wymiarową zespolenia otrzymanego po wciśnięciu tuleje muszą charakteryzować się powtarzalnymi i stabilnymi w czasie wymiarami, które zapewnią możliwość uzyskania żądanego pasowania po siłowym osadzeniu w obudowie. Niezwykle istotna jest także wytrzymałość mechaniczna tulei, niezbędna do prawidłowego montażu w korpusie. Pasowania pomiędzy tuleją a piastą, ze względu na występowanie znacznych obciążeń użytkowych, charakteryzują się dużą wartością wcisku montażowego. Podczas procesu wciskania na tuleję oddziaływają obciążenia, które w przypadku małej wytrzymałości polimeru mogą prowadzić do niedopuszczalnych deformacji lub mechanicznego uszkodzenia osadzanego elementu.

Zastosowanie nylonu jako materiału konstrukcyjnego, oprócz niewątpliwych zalet użytkowych, wywołuje jednak szereg problemów technologicznych. Nylon charakteryzuje się zdecydowanie większą higroskopijnością niż inne tworzywa sztuczne [3-5]. W przypadku nylonu zawartość wilgoci zarówno w materiale surowca, jak i gotowym wyrobie skutkuje znacznym pogorszeniem właściwości mechanicznych oraz zwiększeniem wymiarów gabarytowych. Dla nylonu wzmacnianego włóknem szklanym dodatkowym utrudnieniem jest możliwość znacznego pogorszenia właściwości wyrobu, w zależności od udziału materiału wtórnego w całej masie tworzywa doprowadzonego do wtryskarki. Przyczyną tego zjawiska jest przede wszystkim pękanie włókien podczas mielenia tworzywa wtórnego [6]. Wymienione czynniki w znacznym stopniu mogą powodować utrudnienia w montażu tulejek nylonowych, spowodowane utratą wymaganej wytrzymałości lub niekontrolowanym zwiększeniem wymiarów. Ze względu na przekroczenie dopuszczalnych naprężeń elementy takie ulegają uszkodzeniu w procesie montażu, znacznie zakłócając proces produkcji (rys. 1.). Innym negatywnym skutkiem nieprzestrzegania wymagań technologicznych w produkcji tulei nylonowych jest duże prawdopodobieństwo otrzymania wyrobu wadliwego wykonanego poza dopuszczalnym polem tolerancji. Tuleje ponadwymiarowe osadzone wciskowo w piaście charakteryzują się zbyt ciasnym pasowaniem otworu wewnętrznego, co jakościowo wyklucza otrzymane zespolenie i klasyfikuje gotowy produkt jako brak.

Przestrzeganie wymagań technologicznych w produkcji elementów wykonywanych z nylonu za pomocą technologii wtrysku ciśnieniowego jest działaniem podstawowym i obligatoryjnym [7-9]. W systemie zarządzania jakością istnieje jednak bezwzględna konieczność prowadzenia bieżącej kontroli produktów. Głównym zadaniem kontroli jest zapewnienie szybkiego sprzężenia zwrot- 
Rys. 1. Tuleja uszkodzona podczas montażu

Fig. 1. The bushing damaged during assembly

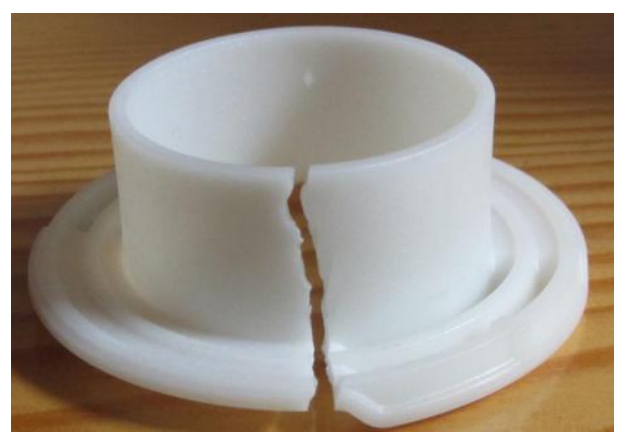

nego w procesie wytwarzania elementów formowanych ciśnieniowo oraz zapobieganie uwolnieniu partii wyrobów o parametrach niezgodnych z wymaganiami konstrukcyjnymi. Najtrudniejszym etapem w procesie wytwarzania tulei jest prawidłowa ocena wyrobu gotowego. Pomiar wilgotności tworzywa oraz kontrola metrologiczna nie dostarczają wszystkich niezbędnych informacji do przeprowadzenia wiarygodnej końcowej oceny jakościowej. Konieczne jest zatem przeprowadzanie prób wytrzymałościowych, których wyniki zapewnią ostateczną weryfikację produktu. Podstawowym zadaniem kontrolnego testu wytrzymałościowego przeprowadzanego na wyrobie gotowym jest odzwierciedlenie wymuszeń w sposób zbliżony do rzeczywistych warunków użytkowania. W przypadku tulei nylonowych procesem określającym wymaganą ich wytrzymałość jest operacja wciskania w piastę łącznika elastycznego.

\section{Metoda badań}

Metodą badań wytrzymałościowych odzwierciedlających warunki zbliżone do rzeczywistych warunków obciążania jest roztłaczanie tulei polimerowej. Metoda badawcza polega na statycznym zagłębianiu stalowego stożka w otworze tulei, aż do wywołania mechanicznego uszkodzenia badanego obiektu. W czasie testu jest rejestrowana wartość siły wzdłużnej oddziałującej na stożek oraz przemieszczenie stożka (rys. 2.). W celu skasowania luzów rejestracja parametrów rozpoczyna się po osiągnięciu wymaganej wartości obciążenia wstępnego. W przyjętej metodzie badawczej oddziaływanie stożka roztłaczającego na czoło tulei jest podobne do oddziaływania narzędzia montażowego wykorzystywanego w operacji wtłaczania tulei w gniazdo osadcze.

Badania przeprowadzono dla dwóch rodzajów tulei wykonanych z tworzywa Zytel 79G13 firmy DuPount. Zytel 79G13 to tworzywo konstrukcyjne z grupy poliamidów (nylon) wzmacniane 13\% dodatkiem włókien szklanych [10]. Tuleje są formowane $\mathrm{w}$ technologii wtrysku ciśnieniowego. Tuleje posiadają kołnierz oporowy, który konstrukcyjnie pełni rolę elementu osadczego. Ponadto spełnia on także funkcję technologiczną, ponieważ dzięki zwiększeniu pola przekroju poprzecznego tuleja może przenosić większe obciążenia montażowe 
pochodzące od narzędzia oddziałującego bezpośrednio na kołnierz. W przeprowadzonych testach pierwszym rodzajem obiektu badań były tuleje kołnierzowe z kształtowym pogrubieniem kołnierza występującym na fragmencie obwodu (rys. 3.). Wysokość pogrubienia wynosi $4 \mathrm{~mm}$. Drugim rodzajem obiektu badań były tuleje kołnierzowe $\mathrm{z}$ kołnierzem osłabionym poprzez wybranie pełniące rolę gniazda ustawczego (rys. 4.). Promień kołowego wybrania wynosi $3 \mathrm{~mm}$ i całkowicie przerywa zarys kołnierza. Obie tuleje wykonano z nowego granulatu o wilgotności $10 \%$. W celu wyeliminowania skutków higroskopijności nylonu tuleje przechowywano w hermetycznym opakowaniu chroniącym przed oddziaływaniem wilgoci z powietrza atmosferycznego.

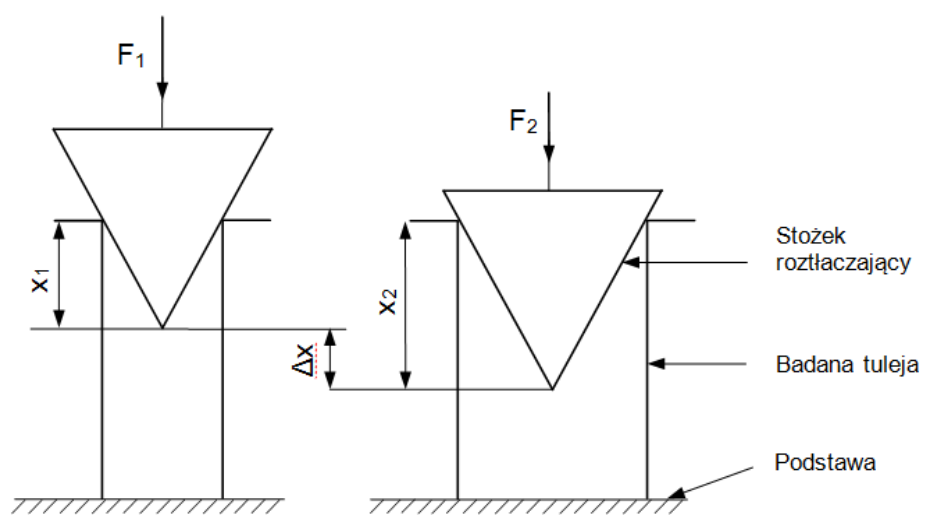

Rys. 2. Schemat metody badań

Fig. 2. The scheme of the research method
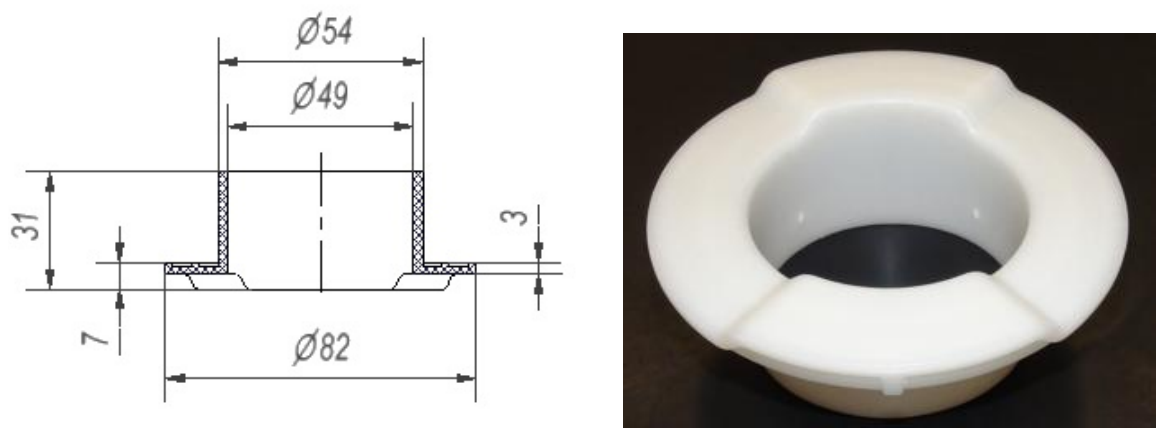

Rys. 3. Tuleja z kołnierzem pogrubionym

Fig. 3. The thickened head-type bushing 
W badaniach zastosowano maszynę wytrzymałościową Instron 5582 wyposażoną w oprogramowanie Bluehill przeznaczone do realizacji testów statycznych. W maszynie wykorzystano przetwornik siły o zakresie pomiarowym $100 \mathrm{kN}$ i dokładności pomiarowej wynoszącej 0,5\% wartości mierzonej siły. Stożek roztłaczający przymocowano do uchwytu przegubowego stanowiącego element belki ruchomej, podstawę zaś do belki nieruchomej (rys. 5.). Badania przeprowadzono za pomocą stożka roztłaczającego (rys. 6.) wykonanego z hartowanej stali, posiadającego szlifowaną boczną powierzchnię roboczą. Kąt zbieżności stożka wynosił $30^{\circ}$ (rys. 6.). Chwyt stożka dopasowano do standardowego mocowania znajdującego się na ruchomej belce maszyny Instron 5582.
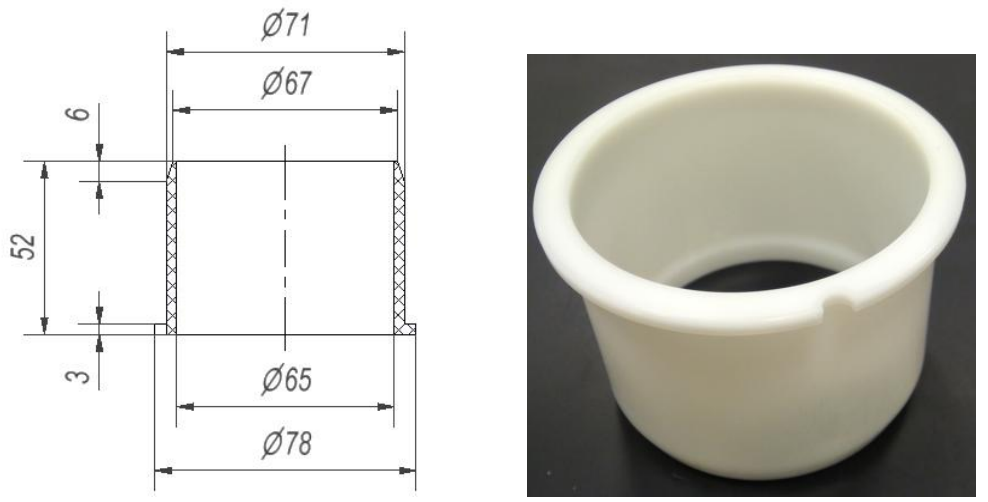

Rys. 4. Tuleja z kołnierzem osłabionym

Fig. 4. The weakened head-type bushing
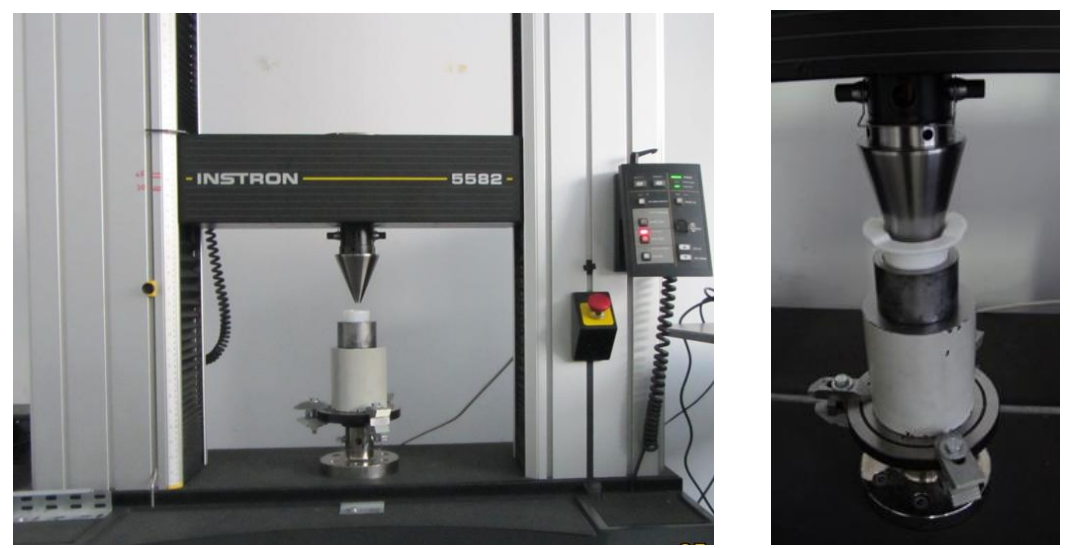

Rys. 5. Stanowisko badawcze

Fig. 5. The test stand 


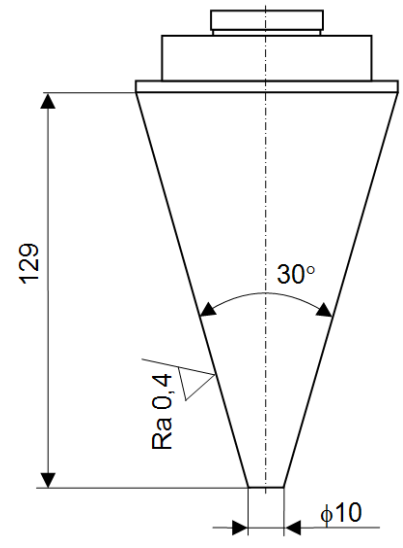

Rys. 6. Stożek roztłaczający

Fig. 6. The expanding cone

\section{Wyniki badań}

Badania przeprowadzono na grupie reprezentowanej przez osiem tulei każdego typu. Obciążanie próbek realizowano z prędkością $50 \mathrm{~mm} / \mathrm{min}$. Wstępne obciążenie wywoływane w celu skasowania luzów wynosiło $100 \mathrm{~N}$. Badania prowadzono do zniszczenia każdej badanej tulei. Charakter uszkodzenia tulei z kołnierzem pogrubionym był zawsze ten sam dla każdego reprezentanta w odpowiedniej grupie badawczej. W każdej tulei wystapiło jednakowe pęknięcie inicjowane w miejscu zmiany przekroju kołnierza. Dalsza propagacja pękania przebiegała dwukierunkowo w taki sposób, że w jej wyniku w ścianie tulei powstawał trójkątny ubytek o wierzchołu znajdującym się na wysokości kołnierza (rys. 7.). Krzywe obciążenia [11] zarejestrowano dla zestawu ośmiu próbek $\mathrm{z}$ kołnierzem pogrubionym (rys. 8.).
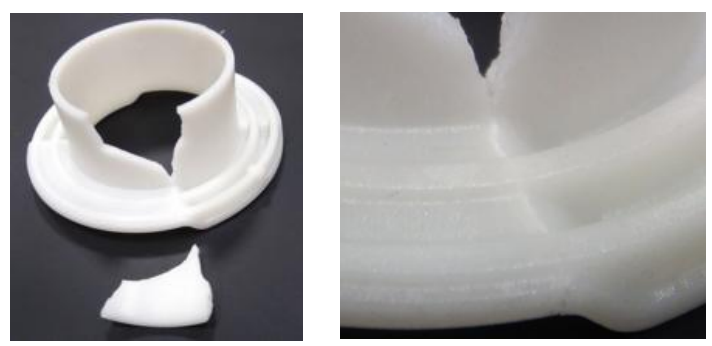

Rys. 7. Pęknięcie tulei z kołnierzem pogrubionym

Fig. 7. The crack of thickened headtype bushing

W przypadku tulei z kołnierzem osłabionym charakter uszkodzenia był również taki sam dla wszystkich reprezentantów w rozpatrywanej grupie badawczej. W każdej tulei wystąpiło jednakowe pęknięcie inicjowane w miejscu największego osłabienia przekroju kołnierza. Dalsza propagacja pękania przebiegała dwukierunkowo, a w jej wyniku w ścianie tulei powstawał trójkątny 


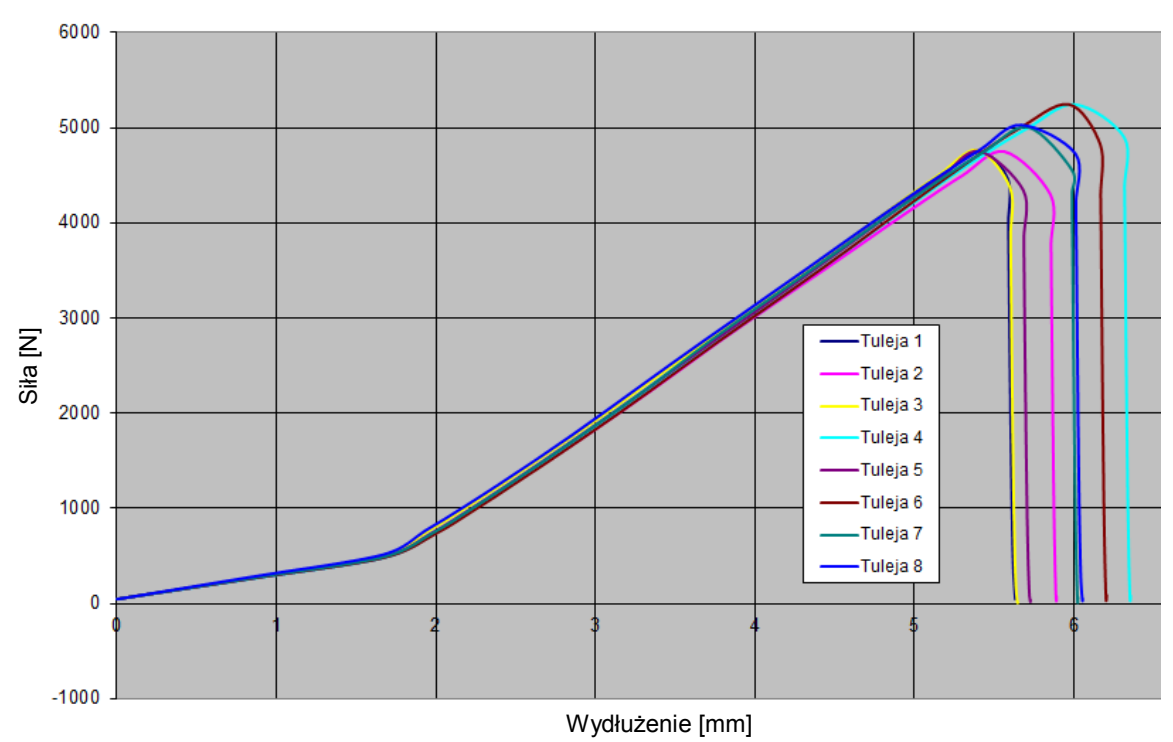

Rys. 8. Wykres obciążenia tulei z kołnierzem pogrubionym

Fig. 8. The load chart for the thickened head-type bushing

ubytek o wierzchołku znajdującym się na wysokości kołnierza (rys. 9.). Krzywe obciążenia zarejestrowano dla zestawu ośmiu próbek z kołnierzem osłabionym (rys. 10.).

Rys. 9. Pęknięcie tulei z kołnierzem osłabionym

Fig. 9. The crack of weakened head-type bushing
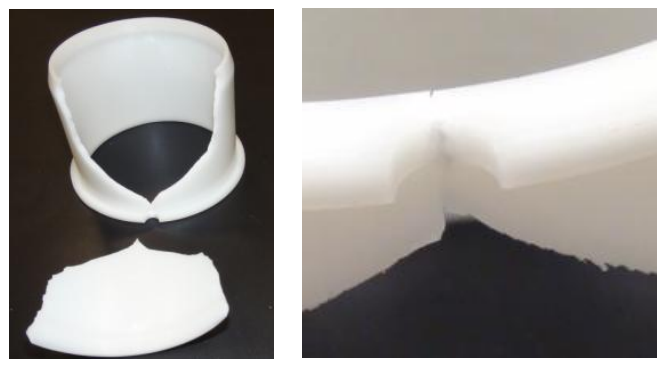

Zarejestrowane charakterystyki obciążenia badanych próbek cechują się stabilnością wyników określających siłę niszczącą, przemieszczenie niszczące i sztywność statyczną badanego układu. Każda z próbek ma jednak swoją indywidualną charakterystykę różniącą się od innych reprezentantów grupy badawczej. Charakter wywołanego uszkodzenia jest bardzo podobny do uszkodzeń powstających w rzeczywistych warunkach wymuszeń siłowych. Tuleje pękają w miejscach najbardziej podatnych na wystapienie uszkodzenia. W przypadku tulei $\mathrm{z}$ kołnierzem pogrubionym jest to miejsce gwałtownej zmiany przekroju znajdujące się na granicy pogrubienia, w przypadku zaś tulei z kołnierzem osła- 
bionym jest to miejsce o najmniejszym polu powierzchni przekroju poprzecznego związane z położeniem gniazda ustawczego. Zarejestrowane charakterystyki obciążania wykazują jednak znaczną różnicę w przebiegu procesu dla obu grup badawczych.

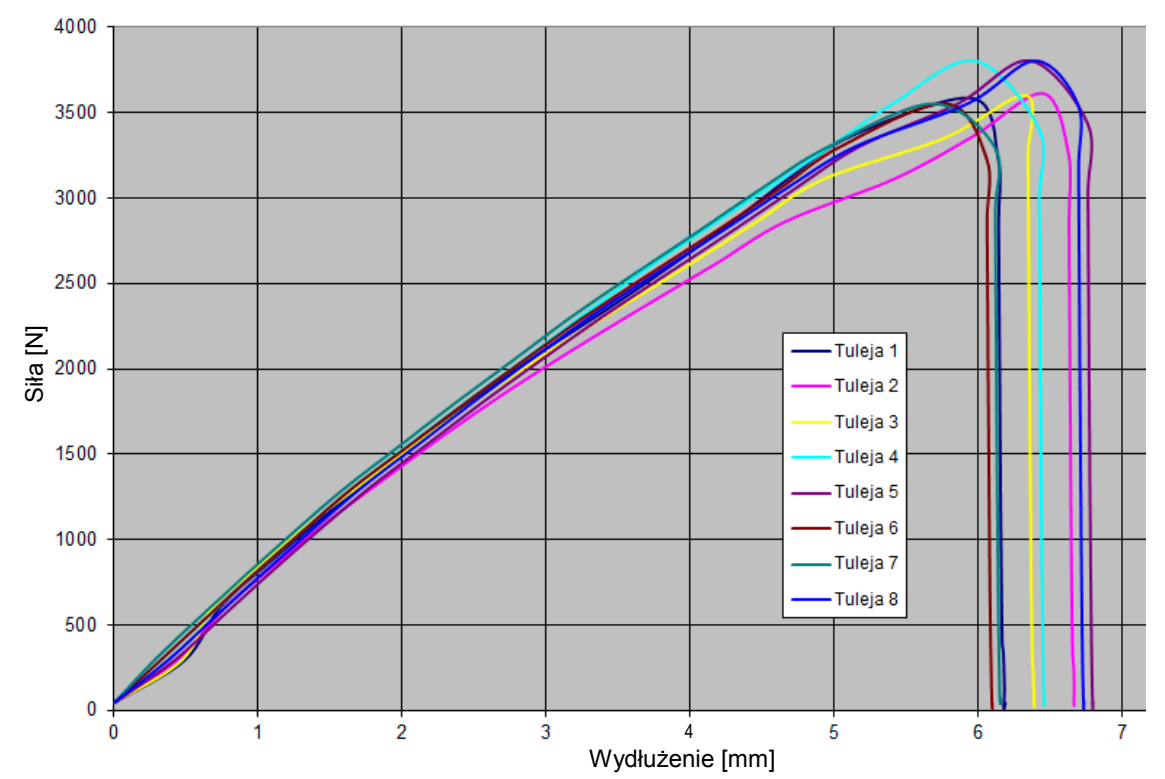

Rys. 10. Wykres obciążenia tulei z kołnierzem osłabionym

Fig. 10. The load chart for the weakened head-type bushing

W przypadku tulei z kołnierzem osłabionym przebieg charakterystyki obciążenia ma charakter jednostajny - zbliżony do liniowego. Dla tulei z kołnierzem pogrubionym charakterystyka ma zdecydowanie charakter nieliniowy. Występują na niej dwa przedziały zmienności gradientu zarejestrowanej funkcji. W pierwszym przedziale sztywność statyczna badanego układu jest wyraźnie mniejsza. Dopiero po przekroczeniu określonej wartości przemieszczenia następuje umocnienie charakteryzujące się znacznym przyrostem sztywności statycznej. Efekt ten jest spowodowany odziaływaniem pogrubienia znajdującego się na kołnierzu. W pierwszej fazie badań stożek penetracyjny oddziałuje jedynie na pogrubienie, co jest zarejestrowane w postaci przedziału o małej sztywności. W kolejnym etapie zostaje nawiązany kontakt z pełnym obwodem pierścienia, co dokumentuje pojawienie się przedziału o znacznie większej sztywności.

\section{Wnioski}

Zaprezentowana metoda badań charakteryzuje się właściwą odtwarzalnością rzeczywistych warunków wymuszeń mechanicznych pojawiających się 
w procesie montażu analizowanych tulei. Zarejestrowane przebiegi mają stabilny charakter i umożliwiają prowadzenie analizy statystycznej wykonywanej na potrzeby kontroli jakości wytwarzanych elementów. Czułość metody jest na tyle duża, że pozwala na precyzyjne wnioskowanie o rodzaju badanej tulei na podstawie zarejestrowanej charakterystyki obciążenia. Opierając się na wynikach przeprowadzonych badań, stwierdzono, że metodę można stosować w bieżącej kontroli jakości gotowych wyrobów występujących w postaci tulei, otrzymywanych z nylonu w technologii wtrysku ciśnieniowego.

\section{Literatura}

1. Osiński Z.: Tłumienie drgań. Wydawnictwo Naukowe PWN, Warszawa 1997.

2. Reński A.: Budowa samochodów. Układy hamulcowe i kierownicze oraz zawieszenia. Oficyna Wydawnicza Politechniki Warszawskiej, Warszawa 2004.

3. Zawistowski H.: Wytłaczanie tworzyw sztucznych. PLASTECH Wydaw. Poradników i Książek Technicznych, Warszawa 1999.

4. Frącz W., Krywult B.: Projektowanie i wytwarzanie elementów z tworzyw sztucznych. Oficyna Wydawnicza Politechniki Rzeszowskiej, Rzeszów 2005.

5. Wilczyński K.: Przetwórstwo tworzyw sztucznych. Oficyna Wydawnicza Politechniki Warszawskiej, Warszawa 2000.

6. Leda H.: Kompozyty polimerowe z włóknami ciagłymi. Wydawnictwo Politechniki Poznańskiej, Poznań 2000.

7. Krywult B., Frącz W.: Wsparcie projektanta. Plastics Review, no 35 (2004), pp. 96-100.

8. Stasiek J.: Wytłaczanie tworzyw polimerowych. Zagadnienia wybrane. Wydaw. Uczelniane Uniwersytetu Technologiczno-Przyrodniczego, Bydgoszcz 2007.

9. Frącz W., Trzepieciński T.: Optymalizacja i prognozowanie deformacji wyrobów wtryskowych. Przetwórstwo Tworzyw, nr 16 (2010), s. 292-301.

10. DuPont: Poradnik przetwórstwa wtryskowego tworzyw Minlon i Zytel. Wydanie 11/1999.

11. Dylagg Z., Jakubowicz A., Orłoś Z.: Wytrzymałość materiałów. Wydawnictwa Naukowo-Techniczne WNT, Warszawa 2007.

Praca naukowa sfinansowana w ramach badań zleconych przez podmioty gospodarcze.

\section{AN EXPANDING TEST IN THE QUALITY CONTROL OF POLYMER BUSHINGS}

\section{A bstract}

The paper presents the use of the expanding method for polymer bushings made of nylon in the process of quality control of finished products and describes problems related to the assembly technology for the bushings which set the standards for qualitative requirements of dimension and fatigue strength parameters. The authors underline the fact, that the main technological problem, which occurs when forcing a bushing into a metal casing is the polymer cracking, which appears 
due to the impact of the technology power load. The requirements towards the representative control test, which reproduces the input forces similar to those that occur in real-life conditions are also described. The tests were conducted with the use of the expanding method consisting in the pressing of a sampler into a tested element. The used sampler was a steel cone with a $30^{\circ}$ angle. The tests were conducted until each tested bushing got damaged. The use of the described method is presented based on two types of polymer bushings, which are made via pressure injection molding technology for Zytel 79G13 plastics. The tested bushings are an element of flexible joints used in car suspension systems. The first object of the research was a head bushing with a thickened flange that occurs on a fragment of a rim. The second tested object was a head bushing with a flange weakened by a recess playing a role of a jack actuator. The registered characteristics of loads put on samplers show stability of results related to the value of the damaging force, the damaging shift and the stiffness of the tested system. The characteristics of the imposed damage to a great extent resemble casualties, which occur in real-life conditions of forced induction. However, the registered characteristics of loads put on samplers demonstrate a significant difference in the process flow for the two types of the tested head bushings, which is caused by the contrary static stiffness of the tested system for each case under investigation. Based on the results of the undertaken research, the thesis statement was formulated, saying that the method is to be used in the current quality control of finished products, namely the bushings made of nylon via pressure injection molding technology.

Keywords: nylon, assembly technology, cracking, expanding cone

DOI: $10.7862 / \mathrm{rm} .2013 .8$

Otrzymano/received: 25.02 .2013

Zaakceptowano/accepted: 22.04.2013 